\title{
Insulin-like Growth Factor-I Can Mediate Autocrine Proliferation of Human Small Cell Lung Cancer Cell Lines In Vitro
}

\author{
Yoichi Nakanishi," James L. Mulshine," Philip G. Kasprzyk," Ronald B. Natale," Rhoda Maneckjee," Ingalil Avis," \\ Anthony M. Treston, * Adi F. Gazdar, ${ }^{\star}$ John D. Minna," and Frank Cuttitta \\ *National Cancer Institute-Navy Medical Oncology Branch, Division of Cancer Treatment, National Cancer Institute \\ and Naval Hospital, Bethesda, Maryland 20814; and ${ }^{\ddagger}$ Uniformed Services University of the Health Sciences, \\ Department of Defense, Bethesda, Maryland 20814
}

\begin{abstract}
The effect of insulin-like growth factor I (IGF-I) on growth of small cell lung cancer (SCLC) cell lines was studied. Western blot analysis of whole cell lysates of cell lines NCI-H345 and NCI-N417 demonstrated the presence of a 16-kD band consistent with an IGF-I precursor molecule. Scatchard plot analysis of cell line NCI-H345 using ${ }^{125}$ I-labeled IGF-I demonstrated two high affinity specific binding sites $\left(K_{d} 1.3\right.$ and 4.0 $\mathrm{nM}$ with maximal rate $\left(B_{\max }\right) 200$ and $500 \mathrm{fmol} / \mathrm{mg}$ protein, respectively). The exogenous addition of IGF-I, IGF-II, or insulin resulted in marked proliferation of human SCLC cells as evaluated using an in vitro growth assay. These peptides stimulate the growth of SCLC cell lines NCI-H82, NCI-H209, NCI-H345, and NCI-N417. The concentration of IGF-I producing maximal SCLC cell growth was 10-100-fold less than that of insulin or IGF-II, whereas the maximal growth stimulated by the optimal concentration of these peptides were similar. An MAb that specifically binds to the IGF-I receptor (but not to the insulin receptor) mediates a dose-dependent inhibition of cell growth in basal media as well as IGF-I, IGF-II, or insulin-supplemented media. The IGF-I receptor thus appears to be the common pathway for the mitogenic activity by IGF-I, IGF-II, and insulin for human SCLC cell lines. The demonstration of an IGF-I precursor molecule, specific IGF-I receptor binding, IGF-I-mediated growth stimulation, and inhibition of basal cell growth by an MAb to the IGF-I receptor suggests that an IGF-I-like molecule can function in vitro as an autocrine growth factor for human SCLC cell lines.
\end{abstract}

\section{Introduction}

The ability of cancer cells to produce and respond to their own growth factors (autocrine secretion) may be a central mechanism in the process of malignant proliferation (1). The prolif-

Address reprint requests to Dr. James L. Mulshine, NCI-NMOB, Building 8, Room 5101, Naval Hospital, Bethesda, MD 20814.

Portions of this work were presented at the annual meeting of the American Association of Cancer Research, 1987, and were published in abstract form in 1987. Proc. Am. Assoc. Cancer Res. 53:211A. (Abstr.)

Received for publication 8 September 1987 and in revised form 1 March 1988.

The Journal of Clinical Investigation, Inc.

Volume 82, July 1988, 354-359 eration of human small cell lung cancer (SCLC) ${ }^{1}$ cells in response to the autocrine secretion of the neuropeptide, gastrinreleasing peptide (GRP), can be blocked in vitro and in vivo using an anti-GRP MAb (2). The disruption of autocrine secretion of GRP is the basis for a new therapeutic approach that is being evaluated in a clinical trial. SCLC is known to produce a wide variety of peptide hormones (3), and the proliferation of SCLC might also depend on others of its own peptide hormone products (4). If other growth factors for SCLC function through an autocrine-type mechanism, they could provide additional targets for the therapeutic control of SCLC proliferation.

An obvious candidate to evaluate for such autocrine activity is insulin-like growth factor-I (IGF-I), which is a mitogen for many types of cells both in vitro and in vivo $(5,6)$. Several investigators have shown that IGF-I or IGF-I-like peptides are produced and/or released by cultured human tumor cell lines (7-9) of fresh human tumor specimens including some lung cancers $(10,11)$. IGF-I-like peptides have also been implicated as autocrine/paracrine growth factors in human breast cancer (12).

Insulin and IGF-I are peptides that are closely related in their primary structures (13) and biological activities (5). Each hormone binds to its own receptor with high affinity and to the other's with lesser affinity $(14,15)$. Insulin has been found to be one of the potent growth stimulators for SCLC (16), although supraphysiological concentrations of insulin were required for optimal proliferation. In a survey of peptide hormone secretion, insulin was detected in $<10 \%$ of SCLC cell lines (17). King et al. reported that the mitogenic effect of insulin for human fibroblast was not mediated by the insulin receptor, since this effect was not inhibited by polyclonal anti-insulin receptor antibodies known to block ligand binding to the insulin receptor (18). Later studies revealed that the mitogenic effect of insulin on human fibroblasts was mediated by the IGF-I receptor, since a mouse MAb that specifically binds to the IGF-I receptor, $\alpha$ IR3 (19), blocks the mitogenic effects of both IGF-I and insulin in human fibroblasts $(20,21)$. IGF-II, another related member of the IGF family, mediates many of the same effects as IGF-I $(22,23)$. IGF-II binds with lesser affinity to the IGF-I receptor and therefore is less potent in stimulating biological events mediated by that receptor.

1. Abbreviations used in this paper: GRP, gastrin-releasing peptide; IGF, insulin-like growth factor; MTT, 3-(4,5-dimethylthiazol-2-yl)2,5-diphenyl tetrazolium bromide; $\mathbf{R}_{\mathrm{TS}}$, $\mathbf{R P M I}$ medium supplemented with transferrin and selenium; SCLC, small cell lung cancer. 
In this report, we evaluate whether IGF-I or a closely related molecule can function as an autocrine growth factor for SCLC. Consistent with Sporn's original hypothesis, demonstration of peptide production, specific receptor expression, and growth stimulation all within the same cell population are required to document autocrine activity (1). In this paper, we show that an immunologically consistent molecule with IGF-I fulfills these criteria. The clinical aspect of this finding is far reaching because, as with the previously reported SCLC autocrine factor, GRP, the IGF-I-like molecule can potentially be a target for new therapeutic approaches to control malignant proliferation.

\section{Methods}

Cell lines. The details of the characterization of the four human SCLC cell lines used are reported elsewhere (24). These lines were obtained from patients with a confirmed histological diagnosis of SCLC, were tumorigenic in nude mice and were grown in RPMI 1640 medium supplemented with 5\% FCS. The representative SCLC cell lines were two SCLC-variants, NCI-H82 and NCI-N417, and the SCLC-classics, NCI-H209 and NCI-H345. SCLC-variants differ from SCLC-classics by virtue of shorter doubling time, absence of measurable bombesinlike immunoreactivity, low level of L-dopa decarboxylase $(24,25)$, and amplification of the $c-m y c$ oncogene (24-26). Since variant SCLC lines lack detectable expression of the GRP peptide and receptors, it is unclear whether GRP mediates autocrine growth for this subset of SCLC.

Growth factors and chemicals. Recombinant IGF-I was purchased from Kabi AB (Stockholm, Sweden). Bovine insulin, human transferrin, selenium $\left(\mathrm{Na}_{2} \mathrm{SeO}_{2}\right)$, and 3-(4,5-dimethylthiazol-2-yl)-2,5-diphenyl tetrazolium bromide (MTT) were purchased from Sigma Chemical Co. (St. Louis, MO). Human IGF-II was a generous gift from Dr. James Perdue (American Red Cross, Bethesda, MD) and was prepared as previously reported (27). Recombinant human insulin purchased from Eli Lilly (Indianapolis, IN) was used for the Western blot analysis. A synthetic IGF-I fragment (amino acids 53-70) was purchased through Applied Biosystems, Inc. (Foster City, CA). A HPLC purified preparation of ${ }^{125} \mathrm{I}$-labeled IGF-I was purchased through Amersham Corp. (Arlington Heights, IL) and used for the receptor binding analysis.

Antibodies. The mouse MAb to the human placental IGF-I receptor ( $\alpha$ IR-3) was a generous gift from Dr. Steven Jacobs (BurroughsWellcome, Research Triangle Park, NC). The isotypic control antibody, MOPC-21 ( $\left.\mathrm{IgG}_{\mathrm{lk}}\right)$, was purchased from Bionetics Laboratory Products, Litton Bionetics, Inc. (Charleston, SC).

Western blot analysis. Whole cell lysates of two SCLC cell lines, a variant (NCI-N417) and a classic (NCI-H345), were analyzed as previously reported (28). The rabbit antiserum used for these experiments was raised against a synthetic fragment of IGF-I (amino acids 53-70). Specificity of the antiserum for IGF-I was evaluated in radiobinding assays. Antiserum reactivity was detected (at a 1:1,000 dilution) by $I^{125}$-Protein A $(40,000 \mathrm{cpm} /$ well). A binding ratio was calculated (binding ratio = counts per minute test peptide - counts per minute BSA/ counts per minute BSA). Binding ratios were 145 and 139 for IGF-I and IGF-I $\mathrm{I}_{53-70}$, compared with a binding ratio of $<1$ for both insulin and IGF-II.

Receptor assays. Membrane preparations of the cell line NCI-H345 were evaluated for the presence of specific IGF-I receptor sites. The method was similar to previous reports (29) except as specified. The cell line was grown in RPMI-1640 medium in the absence of fetal bovine serum. Cells were collected by centrifugation and the pellets were homogenized with a polytron (Brinkmann Instruments, West-

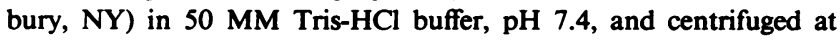
$16,000 \mathrm{rpm}$ for $20 \mathrm{~min}$. The pellet was resuspended in buffer, incubated at $0^{\circ} \mathrm{C}$ for $1 \mathrm{~h}$, and recentrifuged. The pellet was resuspended, recentrifuged at $16,000 \mathrm{rpm}$ for $20 \mathrm{~min}$, and then resuspended in the appropriate volume of buffer. Binding of ${ }^{125}$ I-IGF-I to the intact membranes was then analyzed.

Aliquots of the membrane preparation ( $200 \mu \mathrm{g}$ of protein) were incubated in triplicate for $60 \mathrm{~min}$ at $24^{\circ} \mathrm{C}$ with various concentrations of ${ }^{125} \mathrm{I}$-IGF-I in the presence and absence of excess unlabeled IGF-I and/or insulin. At the end of the incubation period, free ligand was separated from the membrane-bound ligand by filtration under reduced pressure using a disposable manifold (V \& P Scientific, San Diego, CA). The filters were pretreated with $0.01 \%$ poly-L-lysine $+1 \%$ $\mathrm{BSA}$ in $50 \mathrm{nM}$ Tris- $\mathrm{HCl}, \mathrm{pH}$ 7.6. After being washed three times with buffer, the filters were counted in a gamma counter (Micromedic Systems, Inc., Horsham, PA). Specific binding was calculated as the difference between total binding and binding in the presence of the unlabeled ligand. Membrane protein concentrations were determined using the Bio-Rad (Bio-Rad Laboratories, Richmond, CA) protein assay kit. Data for the competition binding studies were analyzed using a computer-assisted linear regression analysis.

MTT assays. The semiautomated colorimetric assay (MTT assay) is based on the ability of cells to reduce a tetrazolium-based compound (MTT) $(30,31)$. Under defined conditions, the cell number is directly proportional to MTT reduction (31), so for the experiments reported here, a doubling of optical density indicated a doubling of cell number. Cells were harvested and washed three times in RPMI 1640 medium. An aliquot of $0.1 \mathrm{ml}$ cell suspension was plated in 96-well tissue culture plates (Costar, Data Packaging Corp., Cambridge, MA). The growth factor solutions $(0.1 \mathrm{ml})$ with/without antibodies in serum-free basal media, which consisted of RPMI 1640 medium plus a final concentration of $10 \mu \mathrm{g} / \mathrm{ml}$ transferrin and $300 \mathrm{nM}$ selenium $\left(R_{\mathrm{TS}}\right)$, were added in each well. Assay conditions were established so that the tumor cells maintained constant growth in $\mathbf{R}_{\mathrm{TS}}$ in excess of the time period analyzed in these experiments. After $7 \mathrm{~d}$ incubation, $0.1 \mathrm{mg}(0.05 \mathrm{ml}$ of 2 $\mathrm{mg} / \mathrm{ml}$ ) MTT was added and the plates were incubated at $37^{\circ} \mathrm{C}$ for $4 \mathrm{~h}$. The plates then were centrifuged at $150 \mathrm{~g}$ for $5 \mathrm{~min}$ and the media were removed. The crystalline-reduced MTT product was solubilized in $0.18 \mathrm{ml}$ DMSO and absorbance was measured using an automated microplate reader (Bio-Tek Instruments, Inc., Burlington, VT) at dual wavelengths of 540 and $690 \mathrm{~nm}$.

\section{Results}

Western blot analysis. A variant SCLC line, NCI-N417, and a classic SCLC cell line, NCI-H345, were analyzed for the expression of IGF-I precursor molecules by Western blot analysis as shown in Fig. 1. A 16-kD band was evident in both cell types using the rabbit anti-IGF-I immune sera. This reactivity was lost if the antisera were preincubated with a $10-\mu \mathrm{M}$ solution of synthetic IGF-I. These data suggest that both types of SCLC cell lines produce a molecule whose immunologic characteristics and molecular weight are consistent with the previously reported IGF-I precursor molecule (22).

Receptor assays. Using ${ }^{125}$ I-IGF-I, the cell line NCI-H345 was shown to contain specific binding sites for IGF-I that were saturable with respect to the radiolabeled ligand concentration. Scatchard plots (not shown) of the radiolabeled ligand binding could be resolved into two linear components with $K_{\mathrm{d}}$ of 1.3 and $4.0 \mathrm{nM}$ and with $B_{\max }$ of $200 \mathrm{fmol} / \mathrm{mg}$ of soluble protein and $500 \mathrm{fmol} / \mathrm{mg}$ of soluble protein, respectively. Analysis of ${ }^{125}$ I-IGF-I binding performed in presence of excess unlabeled insulin showed that insulin was able to displace ${ }^{125} \mathrm{I}$ IGF-I binding from the intact membrane preparations of NCI-H345. Scatchard analysis of the data from binding experiments performed in the presence of cold insulin revealed only the high affinity sites $\left(K_{\mathrm{d}}\right.$ of $2 \mathrm{nM}, B_{\max }$ of $130 \mathrm{fmol} / \mathrm{mg}$ of soluble protein). 


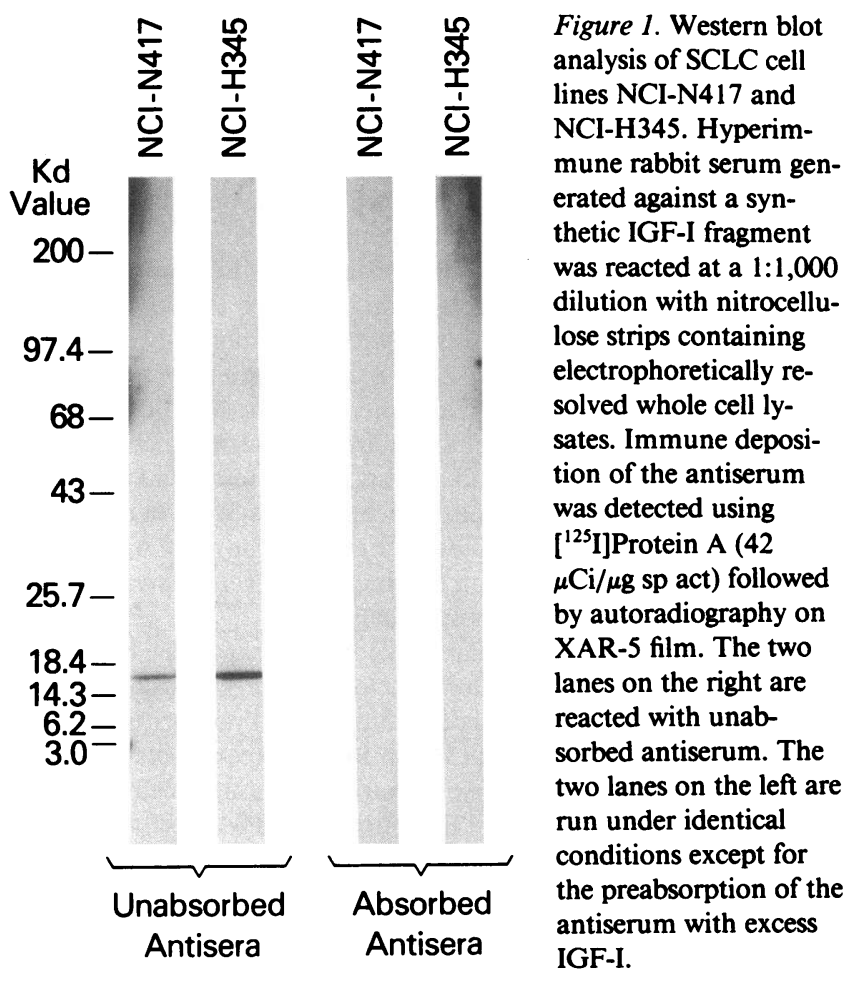

Growth-stimulating effect of exogenous insulin, IGF-I, and $I G F-I I$. Growth of the SCLC cells in various concentrations of IGF-I and IGF-II $(1 \mathrm{pg} / \mathrm{ml}$ to $1 \mu \mathrm{g} / \mathrm{ml})$ or insulin $(1 \mathrm{ng} / \mathrm{ml}$ to 1 $\mathrm{mg} / \mathrm{ml}$ ) was compared with that in basal $R_{T s}$ media not containing these factors. A representative dose response curve for one cell line, NCI-H82, is shown in Fig. 2. The data for the cell lines at the optimal concentration of the peptides are summarized in Table I. The optimal concentration of IGF-I (0.1-1 $\mu \mathrm{g} / \mathrm{ml})$ was $10-100$-fold less than that of insulin (10-100 $\mu \mathrm{g} / \mathrm{ml})$ or IGF-II $(1 \mu \mathrm{g} / \mathrm{ml})$ for all the cell lines. The maximum cell growth for an individual cell line resulting from the addition of optimal concentration of any of the peptides was almost identical. As shown in Table I, the responsiveness to exogenous addition of IGF-I or insulin varied between the individual SCLC cell lines. For the low responder, NCI-N417,

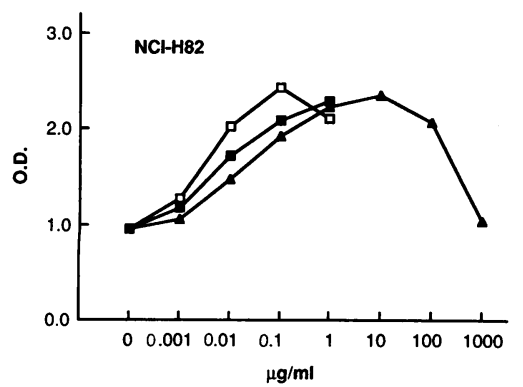

Figure 2. Growth-stimulating effects of insulin, IGF-I, and IGF-II. 2,000 cells/well of SCLC cell line NCI-H82 were seeded in 96-well cell culture plates with RPMI 1640 medium supplemented with final concentrations of $10 \mu \mathrm{g} / \mathrm{ml}$ transferrin and $300 \mathrm{nM}$ se-

lenium $\left(\mathbf{R}_{\mathrm{TS}}\right)$, and indicated concentrations of IGF-I, IGF-II, or insulin were added to each well. After an incubation period of $7 \mathrm{~d}$, the MTT assays were performed as described in Methods. Each data point shows percent growth compared with growth in $\mathrm{R}_{\mathrm{Ts}}$. The experiments were done three times and each data point represents mean \pm SD from six culture wells. $\square$, growth-stimulating effect of IGF-I; $₫$, growth-stimulating effect of insulin; $\boldsymbol{\Sigma}$, growth-stimulating effect of IGF-II.
Table I. Percent Growth Stimulation after Addition of Optimal Concentration of IGF-I, IGF-II, and Insulin

\begin{tabular}{llcl}
\hline Cell line & \multicolumn{1}{c}{ IGF-I } & IGF-II & \multicolumn{1}{c}{ Insulin } \\
\hline & \multicolumn{4}{c}{$\mu g / m l$} \\
NCI-H82 & $257 \pm 21(0.1)$ & $242 \pm 9(1)$ & $242 \pm 15(10)$ \\
NCI-H209 & $259 \pm 6(0.1)$ & ND & $249 \pm 13(1)$ \\
NCI-H345 & $257 \pm 15(1)$ & $231 \pm 11(1)$ & $254 \pm 9(100)$ \\
NCI-N417 & $126 \pm 2(1)$ & ND & $125 \pm 4(10)$
\end{tabular}

Appropriate numbers of cells ( 2,000 cells for NCI-N417, 3,000 cells for NCI-H82, and 20,000 cells for NCI-H209 and NCI-H345) were seeded in 96-well tissue culture plates and cultured with/without various concentrations of the peptides in basal media (RPMI 1640 medium supplemented with final concentrations of $10 \mu \mathrm{g} / \mathrm{ml}$ transferrin and $300 \mathrm{nM}$ selenium; $\mathbf{R}_{\mathrm{TS}}$ ). After $7 \mathrm{~d}$ of incubation periods, the MTT assays were performed. Data are shown only for the concentrations of growth factor resulting in maximum growth stimulation. Each data point represents percent growth after exogenous addition of insulin or IGF-I at the optimal concentrations shown, compared with growth in $R_{\mathrm{TS}}(100 \%)$. Each experiment was repeated three times, and each data point represents mean \pm SD from six culture wells. ND, not done.

growth after the addition of optimal concentrations of IGF-I and insulin was 126.5 and $125.4 \%$ of control, respectively. For the remaining cell lines, the growth was nearly $250 \%$ of control for all peptides.

Effect of $\alpha I R-3$ on basal and stimulated cell growth. The results of the experiments on the four cell lines evaluating the effect of the anti-IGF-I receptor MAb, $\alpha \mathrm{IR}-3$, on the growth of SCLC cells exposed to optimal concentrations of IGF-I or insulin is summarized in Table I. Representative data demonstrating the inhibitory effect of $\alpha \mathrm{IR}-3$, but not the isotypic control antibody, MOPC-21 is shown in Fig. 3. The MAb, $\alpha \mathrm{IR}-3$, inhibited both IGF-I- and insulin-mediated growth of all four SCLC cell lines tested in a dose-dependent fashion as shown in Table II. High concentrations $(10 \mu \mathrm{g} / \mathrm{ml})$ of $\alpha \mathrm{IR}-3$ almost completely blocked the IGF-I- and insulin-mediated cell growth of the four cell lines $(16.3$ to $-147 \%$ of maximum growth). The same concentration of the isotypic control antibody (MOPC-21) had minimal inhibitory effect. The cell line with the least amount of growth in response to exogenous IGF-I or insulin (NCI-N417) had the most marked response to $\alpha$ IR-3 exposure ( -147.5 and $-122.8 \%$ maximum growth), suggesting that at least in this cell line we were seeing antibody inhibition of endogenous IGF-I activity. To test for this, we next evaluated the effect of $\alpha$ IR3 on growth of the SCLC cell lines grown precisely as before, although now in the absence of insulin or IGF-I $\left(\mathbf{R}_{\mathrm{TS}}\right)$. In four separate experiments, the highest concentration of $\alpha \mathrm{IR} 3(10 \mu \mathrm{g} / \mathrm{ml})$ mediated growth inhibition for all four cell lines: with a mean of $28 \%$ for NCI-N417, $26 \%$ for NCI-H82, $22 \%$ for NCI-H345, and $21 \%$ for NCI-H209 compared with growth of cells in $R_{T S}$ alone. Lesser degrees of inhibition were seen at the lower doses of $\alpha \operatorname{IR} 3(0.1,1 \mu \mathrm{g} / \mathrm{ml})$, and no inhibition was seen at any of the three concentration $(0.1,10 \mu \mathrm{g} / \mathrm{ml})$ for an isotypic control antibody, MOPC-21 (data not shown).

\section{Discussion}

Both classic (NCI-H345) and variant (NCI-N417) SCLC lines produce a molecule of the appropriate weight and immuno- 
Table II. Effect of Anti-IGF-I Receptor MAb ( $\alpha I R-3)$ and Isotypic Control (MOPC-21) on IGF-I-mediated and Insulin-mediated Cell Growth

\begin{tabular}{|c|c|c|c|c|c|c|}
\hline \multirow[b]{4}{*}{ Cell line } & \multicolumn{3}{|c|}{$100 \mathrm{ng} / \mathrm{ml} \mathrm{IGF-I}$} & \multicolumn{3}{|c|}{$10 \mu \mathrm{g} / \mathrm{ml}$ insulin } \\
\hline & \multicolumn{3}{|c|}{ Concentration of $\alpha \mathrm{IR}-3$} & \multicolumn{3}{|c|}{ Concentration of $\alpha$ IR-3 } \\
\hline & \multicolumn{3}{|c|}{$\mu g / m l$} & \multicolumn{3}{|c|}{$\mu g / m l$} \\
\hline & 0.1 & 1 & 10 & 0.1 & 1 & 10 \\
\hline NCI-H82 & 105.1 & 64.3 & -11.0 & ND & ND & ND \\
\hline NCI-H209 & 66.3 & 41.2 & 6.8 & 45.1 & 14.1 & -4.6 \\
\hline $\mathrm{NCI}-\mathrm{H} 345$ & 64.3 & 36.3 & -8.7 & 74.0 & 53.7 & 16.3 \\
\hline \multirow[t]{4}{*}{ NCI-N417 } & 100.9 & -15.2 & -147.5 & 98.5 & -42.6 & -122.8 \\
\hline & \multicolumn{3}{|c|}{$100 \mathrm{ng} / \mathrm{ml}$ IGF-I } & \multicolumn{3}{|c|}{$10 \mu \mathrm{g} / \mathrm{ml}$ insulin } \\
\hline & \multicolumn{3}{|c|}{ Concentration of MOPC-21 } & \multicolumn{3}{|c|}{ Concentration of MOPC-21 } \\
\hline & \multicolumn{3}{|c|}{$\mu g / m l$} & \multicolumn{3}{|c|}{$\mu g / m l$} \\
\hline Cell line & 0.1 & 1 & 10 & 0.1 & 1 & 10 \\
\hline NCI-H82 & 127.8 & 95.3 & 106.3 & ND & ND & ND \\
\hline NCI-H209 & 111.4 & 96.6 & 95.8 & 88.3 & 90.0 & 88.4 \\
\hline NCI-H345 & 117.6 & 121.4 & 118.3 & 98.0 & 101.0 & 117.7 \\
\hline NCI-N417 & 100.0 & 83.4 & 112.4 & 79.7 & 96.9 & 86.3 \\
\hline
\end{tabular}

Identical numbers of cells as shown in the legend of Table I were seeded in $R_{T s}+10 \mu g / m l$ insulin or $100 \mathrm{ng} / \mathrm{ml}$ IGF-I with/without the concentrations of $\alpha$ IR-3 or control MAb (MOPC-21) as indicated, incubated $7 \mathrm{~d}$, and growth effects of the antibodies were measured using the MTT assay. Each experiment was done three times. Percent maximum growth was calculated as follows: \% maximum growth $=\left([O D]_{\text {sample media }}\right.$ $\left.-[O D] R_{T S}\right) /\left([O D] R_{T S}+\right.$ IGF-I or insulin - $\left.[O D] R_{T S}\right) \times 100$, so with this equation, $100 \%$ equals growth in $R_{T s}$ with supplementation of optimal amounts of insulin or IGF-I and 0\% equals growth in $R_{T s}$ only. Results are the mean of measurements from 14 wells and varied by $<10 \%$. ND, not done.

logic specificities to be consistent with an IGF-I precursor (22). We have previously reported that dot blot analysis of spent conditioned media from NCI-H345 revealed a molecule that was immunologically cross-reactive with IGF-I (32). Receptor assays demonstrate two classes of binding sites that are present on NCI-H345 consistent with previous characterization of the IGF-I receptor $(29,33)$. Insulin competition experiments confirmed that the binding to the high affinity site was specific for the IGF-I receptor as previously demonstrated (29). The cell
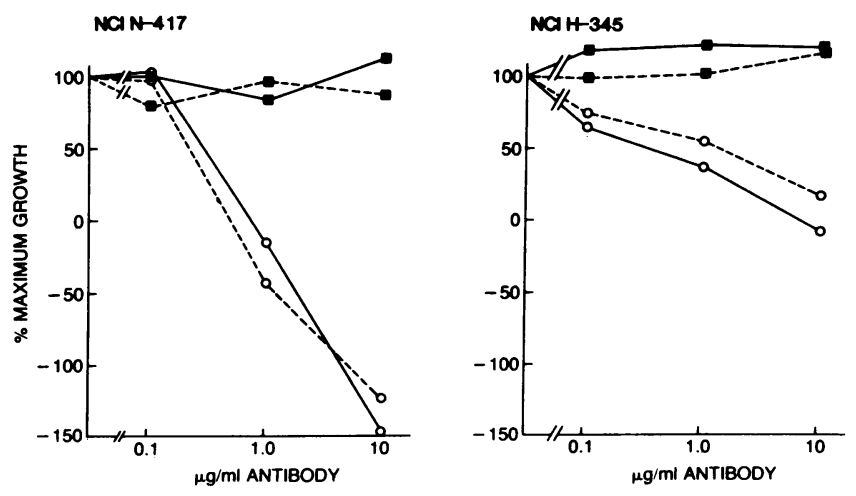

Figure 3. Effect of $\alpha \mathrm{IR}-3$ on the growth of SCLC cell lines. This figure illustrates representative data of the experiments described in Table II. $\bigcirc-0$, effect of $\alpha$ IR-3 on IGF-I-mediated growth; $0---0$, effect of $\alpha \mathrm{IR}-3$ on insulin-mediated growth; - - - effect of MOPC-21 on IGF-I-mediated growth; $---m$, effect of MOPC-21 on insulin-mediated growth. growth experiments have demonstrated that IGF-I and insulin significantly stimulate the growth of four SCLC cell lines. The maximum growth of each SCLC cell line after the exogenous addition of IGF-I, IGF-II, or insulin is similar, but consistently occurs at a 10-100-fold lesser concentration for IGF-I. This situation has been previously reported with other cells in vitro $(15,23)$ and suggests stimulation is mediated by the IGF-I receptor.

The MAb to the IGF-I receptor inhibits both IGF-I and insulin-mediated growth stimulation of human SCLC cell lines in a dose-dependent manner, as shown in Fig. 2 and Table II (IGF-II stimulation was also blocked in a similar fashion by $\alpha$ IR-3, data not shown). These experiments also suggest that the mitogenic effects of IGF-I, IGF-II, and insulin on human SCLC cell lines are predominantly mediated through the IGF-I receptor, as has been previously described in experiments comparing the effect of $\alpha$ IR-3 on IGF-I- and insulinmediated growth of cultured human fibroblasts in serum-free media $(20,21)$. The sensitivity of the SCLC cell lines to exogenous addition of both IGF-I and insulin is varied (Table I). In the four SCLC cell lines tested, the degree of growth inhibition by a high concentration ( $10 \mu \mathrm{g} / \mathrm{ml})$ of $\alpha I R-3$ is inversely related to the sensitivity to exogenous insulin and IGF-I, i.e., the lowest responder to these growth factors, NCI-N417, is the most sensitive to the effect of $\alpha \mathrm{IR}-3$. These results suggest interference of IGF-I-receptor-mediated mitogenesis of both exogenous and endogenous IGF-I activity on SCLC cell lines. Similar experiments conducted in the absence of exogenous IGFs or insulin confirm that the anti-IGF-I receptor antibody inhibits cell growth below baseline, which suggests an auto- 
stimulatory role for an IGF-I-like activity for all four cell lines. The degree of inhibition of growth caused by the anti-IGF-I receptor antibody in basal media (i.e., insulin- or IGF-I-free $\mathbf{R}_{\mathrm{TS}}$ ) was not as marked as that seen when we evaluated the effect of $\alpha$ IR-3 on exogenous IGF-I or insulin. The greater cell growth in the control plates for the cells grown in $\mathbf{R}_{\mathrm{TIS}}\left(\mathbf{R}_{\mathrm{TS}}\right.$ with insulin added) or ( $\mathbf{R}_{\text {TSIGF-I }}\left[\mathbf{R}_{\mathrm{TS}}\right.$ with IGF-I added]) compared with those in $\mathbf{R}_{\mathrm{TS}}$, has a major effect on the calculation of the percent inhibition of growth. Since FCS generally contains significant and variable amounts of IGF-I and other growth factors, it was avoided in these experiments, as with other experiments evaluating growth factor effects $(3,4,20)$ to ensure reproducibility of these results.

In considering the results of the receptor experiments, the effect of endogenous IGF-I activity on radiolabeled ligand binding can not be fully assessed. Endogenous production of an IGF-I molecule may lead to an underestimate of the $K_{\mathrm{D}}$ and $B_{\max }$ of the ligand for the IGF-I receptor due receptor occupancy, though this effect is hard to quantitate in this system. All four cell lines tested respond to exogenous peptide and show growth inhibition in basal conditions after exposure to an anti-IGF-I receptor MAb. Our limited receptor binding analysis suggests that for at least $\mathrm{NCI}-\mathrm{H} 345$, the binding characteristics of the IGF-I receptor are similar to the previously characterized IGF-I receptors $(29,33)$.

We have shown evidence for peptide production, high affinity receptors, and in vitro growth stimulation of IGF-I for SCLC cell lines. The MAb to the IGF-I receptor ( $\alpha$ IR-3) also successfully inhibits the IGF-I- and insulin- (and IGF-II) mediated proliferation of SCLC. IGF-I is more potent on a molar basis than either insulin or IGF-II in stimulating SCLC growth. In light of those findings, the experiments with the antibody to the IGF-I receptor performed in basal media (insulin- or IGF-free) suggest that IGF-I or a very closely related entity can function as an autocrine growth factor for SCLC. We have previously demonstrated that GRP (2) and recently a transferrin-like molecule $(31,34)$ may share this role in SCLC. This is the first example of a solid tumor that is potentially responsive to multiple autocrine factors, and as such provides an unique model for further study of this complex system to ultimately facilitate understanding of the regulation of proliferation in this lethal malignancy.

\section{Acknowledgments}

We would like to thank Dr. Peter S. Nissley, Dr. Steven Jacobs, Dr. Judson J. Van Wyk, and Dr. Robert B. Dickson for helpful discussions.

This work was funded in part by a generous grant from the $G$. Harold and Leila Y. Mathers Charitable Foundation. Dr. Kasprzyk and Dr. M. Treston were recipients of a Hybritech Inc.-NCI collaborative fellowship.

\section{References}

1. Sporn, M.B., and A. B. Roberts. 1985. Autocrine growth factors and cancer. Nature (Lond.). 313:745-748.

2. Cuttitta, F., D. N. Carney, J. L. Mulshine, T. W. Moody, J. Fedorko, A. Fischler, and J. D. Minna. 1985. Bombesin-like peptides can function as autocrine growth factors in human small-cell lung cancer. Nature (Lond.). 316:823-826.

3. Sorenson, G. D., O. S. Pettengill, T. Brinck-Johnsen, C. C. Cate, and L. H. Maurer. 1981. Hormone productoin by cultures by smallcell carcinoma of the lung. Cancer. 47:1289-1296.

4. Carney, D. N., M. Brower, V. Bertness, and H. K. Oie. 1984. Selective growth of human small cell lung cancer cell lines and clinical specimens in serum-free medium. In Methods for Serum-free Culture of Epithelial and Fibroblastic Cells. Alan R. Liss Inc., New York. 57-71.

5. Froesch, E. R., C. Schmid, J. Schwander, and J. Zapf. 1985. Actions of insulin-like growth factors. Annu. Rev. Physiol. 47:443-467.

6. Schoenle, E., J. Zapf, R. E. Humbel, and E. R. Froesch. 1982. Insulin-like growth factor I stimulates growth in hypophysectomized rats. Nature (Lond.). 296:252-253.

7. De Larco, J. E., and G. J. Todaro. 1978. A human fibrosarcoma cell line producing multiplication stimulating activity (MSA)related peptides. Nature (Lond.). 272:356-358.

8. Blatt, J., C. White, S. Dienes, H. Friedman, and T. P. Foley. 1984. Production of an insulin-like growth factor by osteosarcoma. Biochem. Biophys. Res. Commun. 123:373-376.

9. Huff, K. K., D. Kaufman, K. H. Gabbay, E. M. Spencer, M. E. Lippman, and R. B. Dickson. 1986. Secretion of an insulin-like growth factor-I-related protein by human breast cancer cells. Cancer Res. 46:4613-4619.

10. Tricoli, J. V., L. B. Rall, C. P. Karakousis, L. Herrera, N. J. Petrelli, G. I. Bell, and T. B. Shows. 1986. Enhanced levels of insulinlike growth factor messenger RNA in human colon carcinomas and liposarcomas. Cancer Res. 46:6169-6173.

11. Minuto F., P. Del Monte, A. Barreca, P. Fortini, G. Cariola, G. Catrambone, and G. Giordano. 1986. Evidence for an increased somatomedin-C/insulin-like growth factor I content in primary human lung tumors. Cancer Res. 46:985-988.

12. Lippman, M. E., R. B. Dickson, S. Bates, C. Knabbe, K. Huff, S. Swain, M. McManaway, D. Bronzert, A. Kasid, and E. P. Gelmann. 1986. Autocrine and paracrine growth regulation of human breast cancer. Breast Cancer Res. Treat. 7:59-70.

13. Rinderknecht, E., and R. E. Humbel. 1978. The amino acid sequence of human insulin-like growth factor I and its structural homology with proinsulin. $\dot{J}$. Biol. Chem. 253:2769-2776.

14. Van Wyk, J. J., L. E. Underwood, J. B. Baseman, R. L. Hintz, D. R. Clemmons, and R. N. Marshall. 1975. Explorations of the insulin-like and growth-promoting properties of somatomedin by membrane receptor assays. Adv. Metab. Disord. 8:127-150.

15. Borland, K., M. Mita, C. L. Oppenheimer, L. A. Blinderman, J. Massague, P. F. Hall, and M. P. Czech. 1984. The actions of insulinlike growth factors I and II on cultured Sertoli cells. Endocrinology. 114:240-245.

16. Simms, E., A. F. Gazdar, P. G. Abrams, and J. D. Minna. 1980. Growth of human small cell (oat cell) carcinoma of the lung in serumfree growth factor supplemented medium. Cancer Res. 40:4356-4363.

17. Gazdar, A. F., and D. N. Carney. 1984. Endocrine properties of small cell carcinoma of the lung. In The Endocrine Lung in Health \& Disease. K. L. Becker and A. F. Gazdar, editors. W. B. Saunders Co., Philadelphia, PA. 501-508.

18. King, G. L., C. R. Kahn, M. M. Rechler, and S. P. Nissley. 1980. Direct demonstration of separate receptors for growth and metabolic activities of insulin and multiplication-stimulating activity (an insulin-like growth factor) using antibodies to the insulin receptor. $J$. Clin. Invest. 66:130-140.

19. Kull, F. C., S. Jacobs, Y.-F. Su, M. E. Svoboda, J. J. Van Wyk, and P. Cuatrecasas. 1983. Monoclonal antibodies to receptors for insulin and somatomedin-C. J. Biol. Chem. 258:6561-6566.

20. Flier, J. S., P. Usher, and A. C. Moses. 1986. Monoclonal antibody to the type I insulin-like growth factor (IGF-I) receptor blocks IGF-I receptor-mediated DNA synthesis: clarification of the mitogenic mechanisms of IGF-I and insulin in human skin fibroblasts. Proc. Natl. Acad. Sci. USA. 83:664-668.

21. Van Wyk, J. J., D. C. Graves, S. J. Casella, and S. Jacobs. 1985. Evidence from monoclonal antibody studies that insulin stimulates 
deoxyribonucleic acid synthesis through the type I somatomedin receptor. J. Clin. Endocrinol. \& Metab. 61:639-643.

22. Jansen, M., F. M. A. van Schaik, A. T. Ricker, B. Bullock, D. E. Woods, K. H. Gabbay, A. L. Nusbaum, J. S. Sussenbach, and J. L. Van den Brande. 1983. Sequence of cDNA encoding human insulin-like growth factor I precursor. Nature (Lond.). 306:609-611.

23. Rechler, M. W., and S. P. Nissley. 1985. The nature and regulation of the receptors for insulin-like growth factors. Annu. Rev. Physiol. 47:425-442.

24. Carney, D. N., A. F. Gazdar, G. Bepler, J. G. Guccion, P. J. Marrangos, T. W. Moody, M. H. Zweig, and J. D. Minna. 1985. Establishment and identification of small cell lung cancer cell lines having classic and variant features. Cancer Res. 45:2913-2923.

25. Gazdar, A. F., D. N. Carney, M. M. Nau, and J. D. Minna. 1985. Characterization of variant subclasses of cell lines derived from small cell lung cancer having distinctive biochemical, morphological, and growth properties. Cancer Res. 45:2924-2930.

26. Little, C. D., M. M. Nau, D. N. Carney, A. F. Gazdar, and J. D. Minna. 1983. Amplification and expression of the $c-m y c$ oncogene in human lung cancer cell lines. Nature (Lond.). 306:194-196.

27. Gowan, L. K., B. Hampton, D. J. Hill, R. J. Schlueter, and J. F. Purdue. 1987. Purification and characterization of a unique high molecular weight form of insulin-like growth factor II. Endocrinology. 121:449-458.

28. Cuttitta F., J. Fedorko, J. Gu, A.-M. Lebacq-Verheyden, R. I. Linnoila, and J. F. Battey. 1988. Gastrin releasing peptide gene associated peptides (GGAPs) are expressed in normal human fetal lung and small cell lung cancer: a novel peptide family found in man. $J$. Clin. Endocrinol \& Metab. In press.

29. Jonas H. A., and L. C. Harrison. 1985. The human placenta contains two distinct binding and immunoreactive species of insulinlike growth factor-I receptors. J. Biol. Chem. 260:2288-2294.

30. Mosmann, T. 1983. Rapid colorimetric assay for cellular growth and survival: application to proliferation and cytotoxicity assays. J. Immunol. Methods. 65:55-63.

31. Nakanishi, Y., F. Cuttitta, P. G. Kasprzyk, I. Avis, S. M. Steinberg, A. F. Gazdar, and J. L. Mulshine. 1988. Growth factor effects on small cell lung cancer cells using a colorimetric assay: can a transferrin-like factor mediate autocrine growth? Exp. Cell Biol. In press.

32. Cuttitta, F., M. L. Levitt, J. G. Park, P. Kasprzyk, Y. Nakanishi, J. Reeve, J. Walsh, J. Mulshine, A. Gazdar, and J. Minna. 1987. Growth of human cancer cell lines in unsupplemented basal media as a means of identifying autocrine growth factors. Proc. Am. Assoc. Cancer Res. 28:27. (Abstr.).

33. Tollefsen, S. E., K. Thompson, and D. J. Petersen. 1987. Separation of the high affinity insulin-growth factor I receptor from low affinity binding sites by affinity chromatography. J. Biol. Chem. 262:16461-16469.

34. Nakanishi, Y., F. Cuttitta, P. G. Kasprzyk, A. M. Treston, I. Avis, J. D. Minna, H. K. Kleinman, and J. L. Mulshine. 1988. The effects of growth factors on the in vitro growth of small cell lung cancer as determined in the colorimetric assay. In Lung Cancer Biology. S. Rosen, J. Mulshine, F. Cuttitta, and P. Abrams, editors. Marcel Dekker Inc., New York. In press. 